\title{
Indonesia's Islamic Revolution
}

CAMBRIDGE: CAMBRIDGE UNIVERSITY PRESS, 2020. 270 PAGES.

\section{KEVIN FOGG}

In the years following the end of the Second World War, Indonesia witnessed fierce confrontations between locals and the returning colonial powers. Close to a hundred thousand or more lives were wasted, millions of others were displaced, and daily life was wrought with shortages, suffering, and uncertainties. Dubbed the "Indonesian Revolution," this watershed moment in Southeast Asian history lasted for four long years, culminating in the creation of a fragile nation on 27 December 1949 after centuries of Dutch rule. The coming into being of the world's largest Muslim country left in its wake cycles of state violence, civil unrest, and insurgencies: between the reigning government against its detractors, between Islamic forces and secularists, and between those who had differing visions of what an Indonesian nation should look like.

The book under review directs our attention to Islamic dimensions of the Indonesian Revolution. To some extent, this story of has been told by a good number of scholars. Chiara Formichi's Islam and the Making of the Nation (2012) and Remy Madinier's Islam and Politics in Indonesia (2015), among other recent monographs, have delved deeply into the dynamics of Muslim resistance against 
colonial and postcolonial regimes. Kevin Fogg's Indonesia's Islamic Revolution expands the frontiers of the extant literature by shifting the inordinate focus on notable leaders of the revolution (such as Sukarno, Hatta, Sjarir, Natsir, Sutomo, and Sudirman) onto the contributions of the masses, or, the people forgotten by most official narratives. His study moves away from the locally-oriented research on Islamic revolutionary movements operating in different islands of the Indonesian archipelago to make a compelling case for a national-level analysis. Above all, the book interweaves official archival sources with more than ten dozen interviews and conversations with participants and witnesses of the revolution. This final contribution is perhaps the most notable, and makes this study a model for future research on the topic.

The book is divided into two parts and thirteen chapters. Chapter 1 outlines the massive transformations in the Indonesian Muslim population in the twentieth century under Dutch colonial rule through the eve of the second world war. The Dutch policy of sharpening divisions among nominal and pious Muslims and among the traditionalists and reformists paradoxically brought disparate groups closer. Together, they agitated for the independence of Indonesia. Fogg attributes the rise of revolutionary fervor among Muslims to their growing frustrations under the Dutch, which rose to dangerous levels in the Japanese interregnum. During the closing stages of the war, Japanese-sponsored Muslim militias took things into their own hands and this provided the impetus for revolution. Missing in this account was the fact that antipathy toward all things "unIslamic", "secular", and "foreign" among many religiously-inclined Muslims had developed for many decades even prior to the advent of the Japanese. These were the long-term causes of the revolution, so to speak, which needed precipitating or triggering events to spark a full-blown revolution.

Chapters 2-5 are the best and most gripping segments of the book. The ulama, activists, and militias, according to Fogg, used fatwas, manifestoes, amulets, magic, and trances to mobilize and wage fierce battles against the Dutch. How these mediums of 
resistance were so quickly distributed, socially communicated, and rapidly disseminated across different parts of Indonesia and within such a confusing and tumultuous context could have been better explained. While reading the blow-by-blow description which Fogg assiduously provides, I am reminded of Theda Skocpol's dated yet still influential study of the Iranian revolution (in Theory and Society 11:3) where she explained how activist networks in some revolutionary contexts fused and manipulated up-to-date communicative tools with traditional methods of oral communication to spread revolutionary ideas and to swell up support amidst constant reprisals. Skocpol's theoretical insights could have been furthered or even questioned in light of the Indonesian experience. Indeed, Indonesian Islamic revolutionaries, much like their Iranian counterparts, were not always effective in the face of a technologically and strategically superior power. And yet, thanks to their tenacity, persistence, and sophistication in relaying information, Islamic revolutionaries - many of whom were women (66) — did much to inflict severe damage to the Dutch war machinery and the morale of colonial collaborators. The Islamic revolutionaries eradicated remnants of public fear toward the old feudal order and thereby supercharged the pursuit of merdeka (independence).

Much of what Fogg covers in Chapter 6 is quite standard, barely departing from Chiara Formichi's study on the Darul Islam (House of Islam) secessionist movement which traced its roots in West Java and found sympathies in other parts of Indonesia. This chapter is nonetheless significant in that it depicts Darul Islam not as a unique episode in Indonesian history but as part of a larger story of Islamic militant responses to colonialism and its perceived avatars. Chapters 7-12 (forming Part II) share the same limitations as Chapter 6: these chapters shed little new light on the already well-documented events of the Jakarta Charter, the creation and thorny career of Masjumi (Partai Majelis Syuro Muslimin Indonesia, or Council of Indonesian Muslim Associations), the early years of the Ministry of Religion, and the bumpy fates of Islamic parties. 
In these chapters, Fogg could have given more space to considering meso-level or micro-level Islamic actors rather than re-enacting the rather familiar terrain of high-level politics covered in many histories of revolutionary Indonesia. Viewed in totality, however, the second part of the book demonstrates Fogg's overarching point: the Islamic factor of the Indonesian revolution implicated all levels of the Muslim society, young and old, elites and laymen, men and women. Chapter 13 on "Islamic Diplomacy" compensates for the shortcomings of these earlier chapters. There Fogg elucidates the roles of Indonesian students, travellers, and workers based in the Middle East, Australia, United States, and the Czech Republic in rallying the support of foreign governments and institutions to advance their cause for self-determination. Diplomacy just as much as militancy was a potent part of the battles for independence. A book-length study of the roles of Indonesian Muslims overseas in the shaping of the new nation-state, during the heat of the revolution and the years immediately after, is now sorely needed. We are thankful to Fogg for opening our eyes to this historiographical gap.

A valued resource and soon-to-be a staple for many courses on Islam in the modern world, scholars writing on anti-colonial revolutions and on revolutions in general may well find this book useful as a basis of comparison for investigating the use and abuse of religions in liberation movements.

Khairudin Aljunied

Associate Professor, Faculty of Arts and Social Sciences National University of Singapore, Singapore

doi: 10.35632/ajis.v38il-2.2929 